\title{
Ultrastructural identification of a herpes-like virus infection in common carp Cyprinus carpio in Korea
}

\author{
Dong Lim Choi*, Sang Gyu Sohn, Jong Deuk Bang, Jeong Wan Do, Mi Seon Park
}

Pathology Division, National Fisheries Research and Development Institute, 408-1 Silang, Gijang, Busan 612-900, Republic of Korea

\begin{abstract}
We report on a herpes-like virus, which was found to be associated with mass mortality of common carp Cyprinus carpio for the first time in Korea in 1998. The external signs of infection in moribund fish were darkened coloration and severe branchial necrosis in the gill. Transmission electron microscopy revealed the presence of herpes-like viruses in spleen tissue. Infected spleen cells showed hypertrophied nuclei and degeneration. Numerous nucleocapsids of about $82 \mathrm{~nm}$ in diameter were found within the nucleus and cytoplasm of infected cells, and extracellular enveloped particles were also observed. We conclude that this virus was a likely significant cause of the high mortality of common carp in Korea in 1998.
\end{abstract}

KEY WORDS: Herpes-like virus · Common carp · Cyprinus carpio $\cdot$ Mortality Resale or republication not permitted without written consent of the publisher

\section{INTRODUCTION}

Several herpes-like viruses have been detected in different fish species, but only a few have been sufficiently characterized (Essbauer \& Ahne 2001). Recently, a newly recognized herpesvirus disease has caused outbreaks involving mass mortality in common carp Cyprinus carpio and its colorful variety, designated as koi or fancy carp (Hedrick et al. 2000). Mortalities in koi carp caused by herpesvirus have been reported from Israel (Ariav et al. 1999), Germany (Bretzinger et al. 1999) and the USA (Hedrick et al. 2000).

During both the spring and summer of 1998, an epizootic disease with severe mortality occurred in Korea among cultured common and Israeli carp. Herein we describe for the first time a herpes-like virus infecting common carp during this period. We suggest that this herpes-like virus may be one factor responsible for the high mortality of common carp in Korea during this period.

\section{MATERIALS AND METHODS}

Gross examination. Diseased common carp Cyprinus carpio were collected in June 1998 from an outbreak farm located in Gangwon, Korea.

Transmission electron microscopy. Spleen tissues from 2 moribund fish were fixed in $2.5 \%$ glutaraldehyde in $0.2 \mathrm{M}$ cacodylate buffer ( $\mathrm{pH} \mathrm{7.2)}$ ) for $4 \mathrm{~h}$ at $4^{\circ} \mathrm{C}$. After 2 washes in cacodylate buffer, samples were postfixed in $2 \%$ aqueous $\mathrm{OsO}_{4}$ in the same buffer at $4^{\circ} \mathrm{C}$. Samples were dehydrated by serial ethanol baths (70 to $100 \%$ ), cleared twice for $15 \mathrm{~min}$ in propylene oxide and infiltrated for $1 \mathrm{~h}$ in 1:1 propylene oxide: Epon resin. After a further $1 \mathrm{~h}$ infiltration in pure Epon resin, samples were embedded in resin. For light microscopy, $1 \mu \mathrm{m}$ sections were stained in $2.5 \%$ toluidine blue in $1 \%$ aqueous sodium borate solution. For electron microscopy, thin sections were collected on copper grids and double stained with $4 \%$ uranyl acetate and lead citrate prior to examination with a JEOL 1200 EX-2 transmission electron microscope at $80 \mathrm{kV}$. 


\section{RESULTS}

\section{Outbreaks and gross pathological signs}

In May 1998, several farms in Gangwon reported losses among common carp of all ages. The disease spread rapidly to most farms all over the nation. Additional high losses of common carp occurred in 37 out of 44 farms in August 1998. The mass mortality inflicted by the disease was $71.7 \%$, with an absolute loss of $3500 \mathrm{t}$ of common carp and Israeli carp intended for the table. Affected fish had darkened coloration of the skin and severe branchial necrosis in the gill (Fig. 1). Some dead fish showed hemorrhages at the base of the fins and a sunken appearance of the eyes. Internal signs were inconsistent, with adhesions being the only common finding.

\section{Transmission electron microscopy}

Infected spleen cells showed hypertrophied nuclei and degeneration (Fig. 2). Nuclear changes included severe hypertrophy and a diffuse appearance to the chromatin. Intranuclear virus-like particles (Fig. 3a) were observed mainly in hypertrophied cells. The nuclear particles were circular or polygonal in shape, and 78 to $84 \mathrm{~nm}(\mathrm{n}=30)$ in diameter (edge to edge). Some nuclear particles appeared empty and were interpreted as being capsids (Fig. 3a). Others contained an electron-dense toroidal or brick-shaped core, or a concentric ring structure, and were assumed to be nucleocapsids (Fig. 3b). Capsids and nucleocapsids were scattered throughout the nucleus of infected cells (Fig. 3a). Most cytoplasmic particles exhibited a nucleocapsid with a toroidal core (Fig. 4). Extracellular viruses were enveloped and measured around $133 \mathrm{~nm}$ in diameter (edge to edge) (Fig. 5). They contained

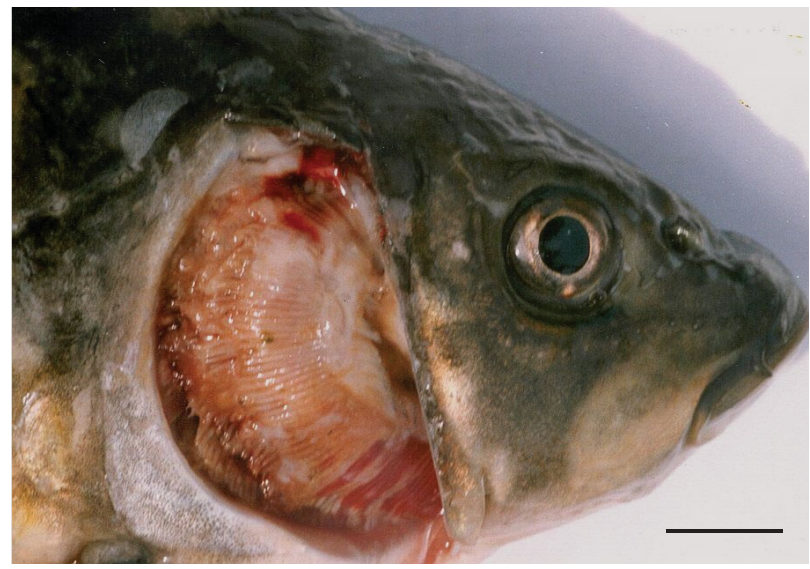

Fig. 1. Cyprinus carpio. Diseased fish with pale and irregular coloration of the gill. Scale bar $=1 \mathrm{~cm}$

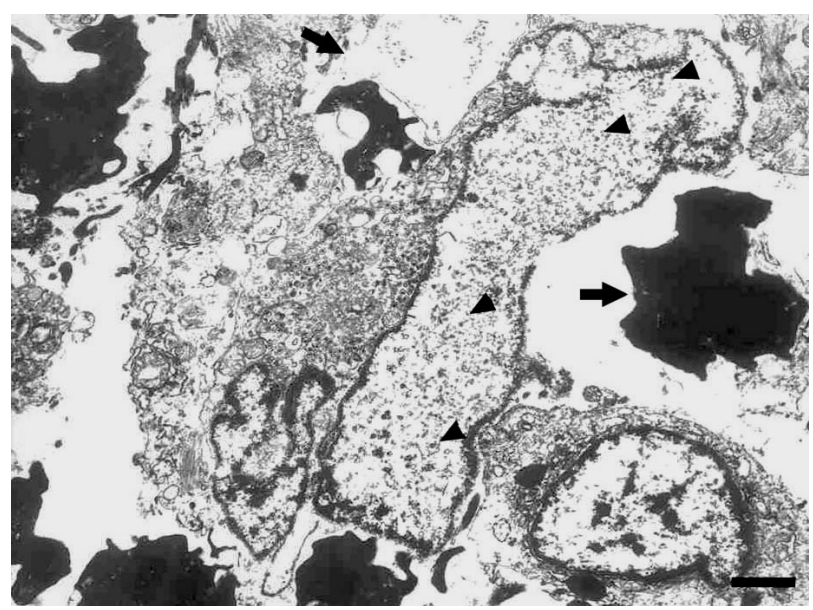

Fig. 2. Spleen tissue showing hypertrophied nuclei with herpes-like viruses (arrowheads) and degeneration of infected cells (arrows). Scale bar $=1 \mu \mathrm{m}$

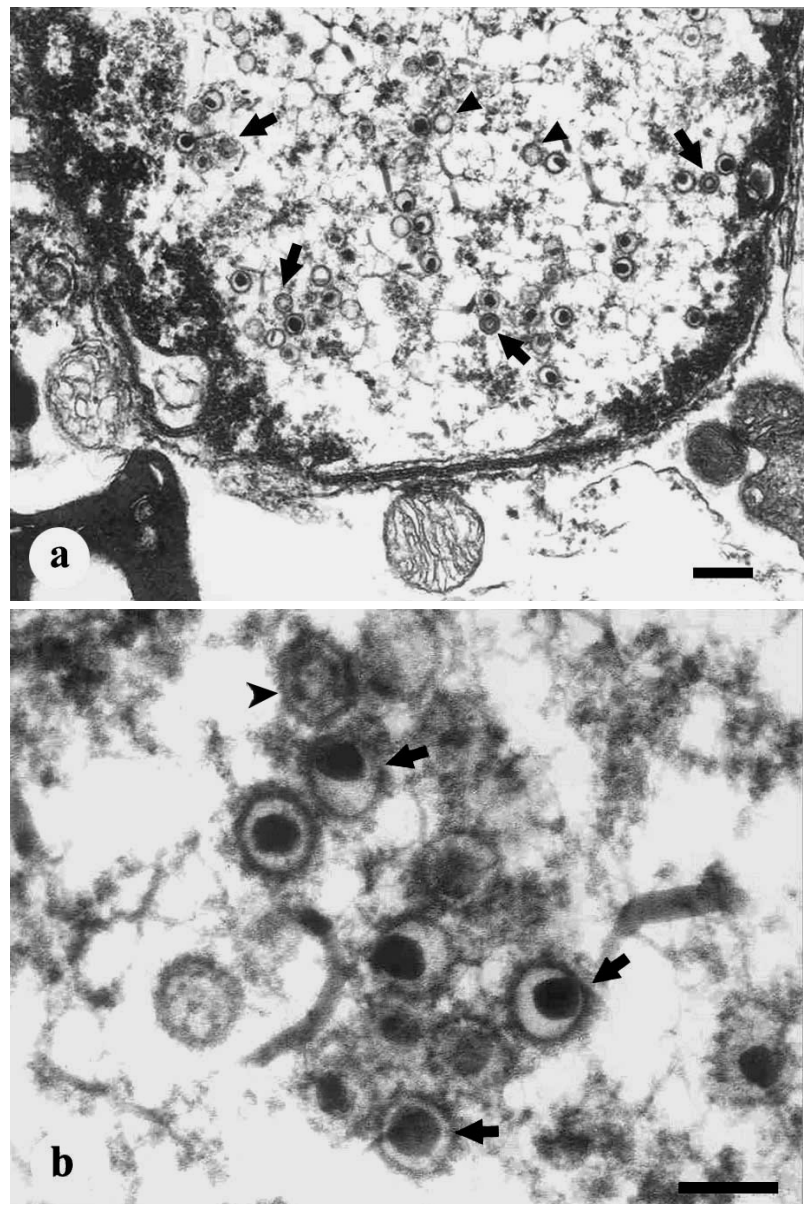

Fig. 3. Nuclei of infected spleen cell containing empty capsids and nucleocapsids. (a) Empty capsids (arrowheads) and nucleocapsids with a double concentric structure (arrows) Scale bar $=200 \mathrm{~nm}$. (b) High magnification of intranuclear nucleocapsids with electron-dense toroidal cores (arrows) and a nucleocapsid with a double concentric structure (arrowhead). Scale bar $=100 \mathrm{~nm}$ 


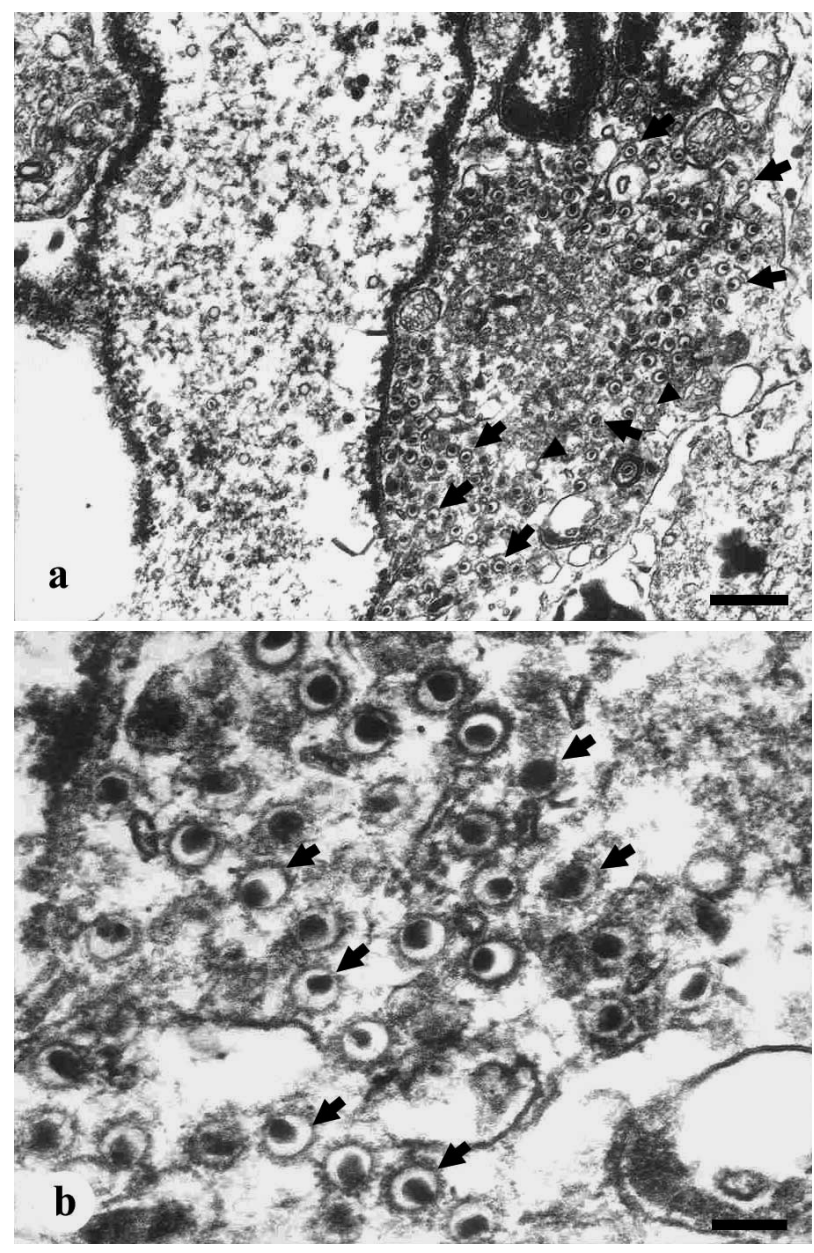

Fig. 4. Cytoplasm of infected spleen cell containing empty capsids and nucleocapsids. (a) Empty capsids (arrowheads) and nucleocapsids with toroidal core (arrows). Scale bar $=500 \mathrm{~nm}$. (b) Nucleocapsids (arrows) in cytoplasm. Scale bar $=100 \mathrm{~nm}$

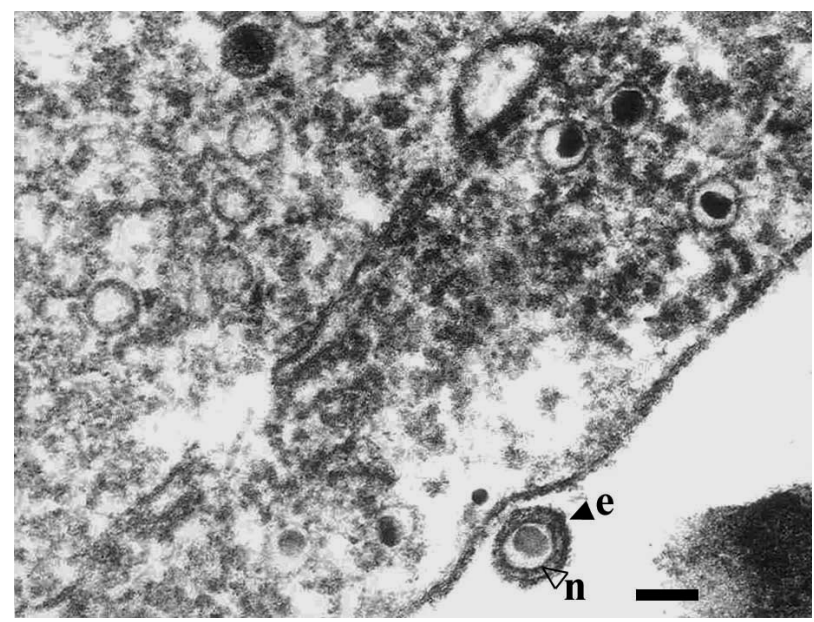

Fig. 5. Fine structure of an extracellular enveloped virus particle. The nucleocapsid (n) is surrounded by an envelope (e). Scale bar $=100 \mathrm{~nm}$ identically shaped and sized elements, with the same structures as the intranuclear and intracytoplasmic particles. The envelope and nucleocapsid were separated by an electron-lucent gap of approximately $10 \mathrm{~nm}$. No tail was observed or any obvious tegument or reduced tegument between the outer membrane and the capsid (Fig. 5).

\section{DISCUSSION}

We describe for the first time a herpes-like virus associated with the high mortality of common carp in Korea in 1998. Virogenesis occurs mainly in cells, as evidenced by the morphological features and the location of virus-like particles within spleen tissues of infected common carp Cyprinus carpio. It begins in the nucleus, where capsids and nucleocapsids appear. The viral particles then pass through the nuclear membranes into the cytoplasm, and enveloped virions are released at the cell surface. The virus described in this report resembles herpesvirus in its morphological characteristics, cellular location and particle size (Roizman 1982, Roizman \& Baines 1991). Intranuclear and cytoplasmic herpesvirus nucleocapsids present a variety of morphological forms. The capsids lacking an electron-dense core can be referred to as empty capsids (Perdue et al. 1976). Nucleocapsids include several capsid types: toroidal core-containing capsids referred to as 'DNA rich' (Perdue et al. 1976), electron-lucent capsids and capsids that appear as 2 concentric rings.

Several herpes-like viruses have been detected in different fish species (Sano et al. 1985, Bekesi et al. 1986, Hedrick et al. 1990, Chang et al. 2002), including herpesvirus in koi carp (Essbauer \& Ahne 2001). The principal external sign of dying fish infected by koi herpesvirus (KHV) is pale and irregularly colored gills (Hedrick et al. 2000). The gross signs observed in this study were very similar to those seen in KHV-infected carp. However, both the viral nucleocapsids (78 to $84 \mathrm{~nm}$ ) and mature virions (133 nm) observed in this study are smaller than those observed by Hedrick et al. (2000) in koi, measuring 110 and 180 to $230 \mathrm{~nm}$, respectively.

Purification and detailed characterization are necessary to develop sensitive diagnosis methods for the detection of these pathogens and to determine relationships between herpes-like viruses isolated from different fish species. Furthermore, such studies will help the study of the distribution and control of this virus.

Acknowledgements. We thank Mr. K. R. Cho of the Medical School of Inje University, who provided technical assistance. This study was supported by the National Fisheries Research and Development Institute. 


\section{LITERATURE CITED}

Ariav R, Tinman S, Bejerano I (1999) First report of newly emerging viral disease of Cyprinus carpio species in Israel. Proc 9th Int Conf Dis Fish Shellfish. 19-24 September, Rhodes, Greece, p 151

Bekesi L, Horvath I, Kovacsgayer E, Csaba G (1986) Demonstration of herpesvirus-like particles in skin lesions of European eel (Auguilla anguilla). J Appl Ichthyol 2:190-192

Bretzinger A, Fischer-Scheri T, Oumouna M, Hoffman R, Truyen U (1999) Mass mortalities in koi carp, Cyprinus carpio, associated with gill and skin disease. Bull Eur Assoc Fish Pathol 19:182-185

Chang PH, Pan YH, Wu CM, Kuo ST, Chung HY (2002) Isolation and molecular characterization of herpesvirus from culture European eels Anguilla anguilla in Taiwan. Dis Aquat Org 50:111-118

Essbauer S, Ahne W (2001) Viruses of lower vertebrates. J Vet Med B 48:403-475

Editorial responsibility: Jo-Ann Leong,

Kaneohe, Hawaii, USA
Hedrick RP, Groff JM, Okihiro MS, McDowell TS (1990) Herpesvirus detected in papillomatous skin growths of koi carp (Cyprinus carpio). J Wildl Dis 26:578-581

Hedrick RP, Gilad O, Yun S, Spangenberg JV and 5 others (2000) A herpesvirus associated with mass mortality of juvenile and adult koi, a strain of common carp. J Aquat Anim Health 12:44-57

Perdue ML, Cohen JC, Randall CC, O'Callaghan DJ (1976) Biochemical studies of maturation of herpesvirus nucleocapsid species. Virology 74:194-210

Roizman B (1982) The family Herpesviridae. General description, taxonomy and classification. In: Roizman B (ed) The viruses, Vol 1, Herpesviruses. Plenum Press, New York, p 1-23

Roizman B, Baines J (1991) The diversity and unity of Herpesviridae. Comp Immun Microbiol Infect Dis 14:63-79

Sano T, Fukuda H, Furukawa M (1985) Herpesvirus cyprinid: biological and oncogenic properties. Fish Pathol 20: 381-388

Submitted: January 25, 2003; Accepted: February 18, 2004

Proofs received from author(s): September 3, 2004 